Article

\title{
Characterization and Potential Use of Biochar for the Remediation of Coal Mine Waste Containing Efflorescent Salts
}

\author{
Luis Carlos Díaz Muegue ${ }^{1,2, *}$, Julio César Arranz González ${ }^{3}$ and Gustavo Peñuela Mesa ${ }^{2}$ \\ 1 GEAB-CIDTEC, Facultad de Ingeniería, Universidad Popular del Cesar, UPC, Balneario Hurtado Vía Patillal, \\ Valledupar 200001, Colombia \\ 2 Grupo de Investigación Diagnostico y Control de la Contaminación (GDCON), Facultad de Ingeniería, \\ Universidad de Antioquia, UdeA, Calle 70 No 52-21, Medellín 050010, Colombia; \\ gustavo.penuela@udea.edu.co \\ 3 Área de Recursos Energéticos y Sostenibilidad Minera, Instituto Geológico Minero de España, IGME, \\ 28003 Madrid, Spain; jc.arranz@igme.es \\ * Correspondence: luisdiaz@unicesar.edu.co; Tel.: +57-316-427-2944
}

Received: 18 August 2017; Accepted: 3 November 2017; Published: 15 November 2017

\begin{abstract}
In open pit coal mining, soil and vegetation are removed prior to the start of mining activities, causing physical, chemical, and microbiological changes to the soil and landscape. The present work shows the results of an integrated study of the remediation of mine waste with a high level of salt contamination in areas of the Cesar Department (Colombia), employing biochar as an amendment. Physical-chemical properties including Munsell color, texture, $\mathrm{pH}$, electrical conductivity, water-holding capacity, cation exchange capacity, metal content, organic carbon, sulfates, extractable $\mathrm{P}$, and total nitrogen were characterized both in the soils contaminated with mine residues and the biochar sample. A high concentration of sulfates, calcium, iron, and aluminum and a significant presence of $\mathrm{Na}$, followed by minor amounts of $\mathrm{Mg}, \mathrm{K}, \mathrm{Cu}$, and $\mathrm{Mn}$, were observed in efflorescent salts. X-ray diffraction indicated a high presence of quartz and gypsum and the absence of pyrite and Schwertmannite in the efflorescent salt, while showing broad peaks belonging to graphene sheets in the biochar sample. Soil remediation was evaluated in Petri dish seed germination bioassays using Brachiaria decumbens. Biochar was shown to be effective in the improvement of $\mathrm{pH}$, and positively influenced the germination percentage and root length of Brachiaria grass seeds.
\end{abstract}

Keywords: coal mine waste; amendments; efflorescent salts; biochar; germination bioassay

\section{Introduction}

Major environmental problems from coal mining are mostly associated with high concentrations of sulfur, salinity, metals, and acidity [1] produced by surface deposits of waste rocks (mine waste) [2,3]. These components can affect the quality of surface waters and shallow groundwater near the mines. The presence of high concentrations of salts in coal mining soils resulting from the use of coatings rich in salts or as a consequence of the pyrite oxidation in the mine spoils can decrease the productivity of the soil [4]. In particular, dissolution of salt from saline mine spoil during rainfall events may result in local or regional dispersion of salts through leaching, or in the accumulation of dissolved salts in soil pore water and inhibition of plant growth [5]. Therefore, despite the application of amendments to carbonaceous wastes, coal mines can still be a source of high concentrations of metals and dissolved salts such as $\mathrm{Mn}, \mathrm{Zn}, \mathrm{Al}, \mathrm{Fe}, \mathrm{K}, \mathrm{Cu} \mathrm{Se}, \mathrm{Na}, \mathrm{Ca}, \mathrm{Mg}, \mathrm{Cl}, \mathrm{NO}_{3}{ }^{-}$, and $\mathrm{SO}_{4}{ }^{2-}[2,3,6,7]$. Salinity and osmotic tension have been found to be responsible for the inhibition of plant growth and the delay of germination [8]. Salinity adversely affects crop seed germination either through the creation of osmotic 
potential outside the seed, which hinders water absorption, or through the toxic effect of $\mathrm{Na}^{+}$and $\mathrm{Cl}^{-}$ ions $[9,10]$. Salinity is normally evaluated through electrical conductivity $(\mathrm{EC})$ readings of soil solutions or saturated soil pastes, which are highly correlated with the concentration of total salts. Efflorescent salt in coal mine spoil piles is dominated by sulfate salts of sodium, magnesium, and calcium [1], a product of the evaporation of acid mine drainage (AMD) in surficial environments. These minerals can be considered as the highest polluting residue in the mining environment. Because of the high solubility of efflorescent minerals, climate plays an important role in their mineral chemistry [11]. The minerals commonly associated with saline soils are gypsum, thenardite, mirabilite, hexahydrate, epsomite, bloedite, konyaite, loweite, eugstgerite, wattevilleite, halite, nitratine, and natrojarosite [1].

The use of stabilization materials or reagents for the remediation in situ of soils contaminated with metals and organic constituents has been extensively studied, and they are increasingly being accepted as a remediation technology [12]. The main goal of in situ remediation technologies is to stabilize and contain pollutant materials in the soil to reduce their ability to pollute water or biota and thereby reduce their potential for toxicity and transport. These technologies also aim to improve the soil's water retention capacity [13-15], cation exchange capacity (CEC), and the availability of nutrients such as P, Ca, and K [16-18], and to improve mine soil aggregation and root length [19,20]. Recently, soil recalcitrant organic carbon (also known as biochar), which is a black carbon material, has been studied as a soil amendment $[18,21,22]$. The application of biochar improves some physical and chemical soil properties [23]. For example, in one study, biochar application increased soil aggregation, water holding capacity, and cation exchange capacity [24]. The type of biochar and its application rate influence wheat seed germination and seedling growth [25]. However, some studies have reported that maize seed germination and early growth are not significantly affected by biochar [26]. The biochar remediation of $\mathrm{Cu}, \mathrm{Zn}$, and $\mathrm{Cd}$ in soil samples has also been evaluated [27]. The capacity of activated charcoal to absorb a variety of salts has long been noted [28], and charcoal has also been utilized in industrial desalination processes $[29,30]$. However, the potential use of biochar as a soil amendment to mitigate salt-induced plant stress appears to have received essentially no prior research attention. In this way, the use of biochar as an amendment and remediation medium has been widely accepted for soil quality improvement $[18,31]$. Additionally, the presence of graphene in the biochar used for environmental remediation purposes opens up the possibility of new potential applications [32], provides a slow release fertilizer and serves as a microbial inoculum [33,34]. The stimulation or inhibition of seed germination through biochar application has been investigated primarily [25] as a phytotoxic bioassay and for its potential role in the rehabilitation, revegetation, and repair of contaminated soils [35].

The main goal of this work is to assess the action and effectiveness of biochar as an amendment in the remediation of soil contaminated with efflorescent salts in a coal mining area in the north of Colombia.

The research here was aimed to study the effect of biochar from oil palm crop residues on the germination and elongation of the brachiaria grass root in mining soils affected by the presence of efflorescent salts by coal mining activity in Cesar.

\section{Materials and Methods}

\subsection{Site Location and Description of Study Area and Sampling}

Mining waste samples were collected in a coal mining area in the north of Colombia (La Loma, Department of Cesar) (Figure 1). The samples were taken with a spatula, removed from the salt layer, dried to moisture equilibrium for $24 \mathrm{~h}$, and sieved with a mesh to select particles measuring $2 \mathrm{~mm}$ in size or less. 


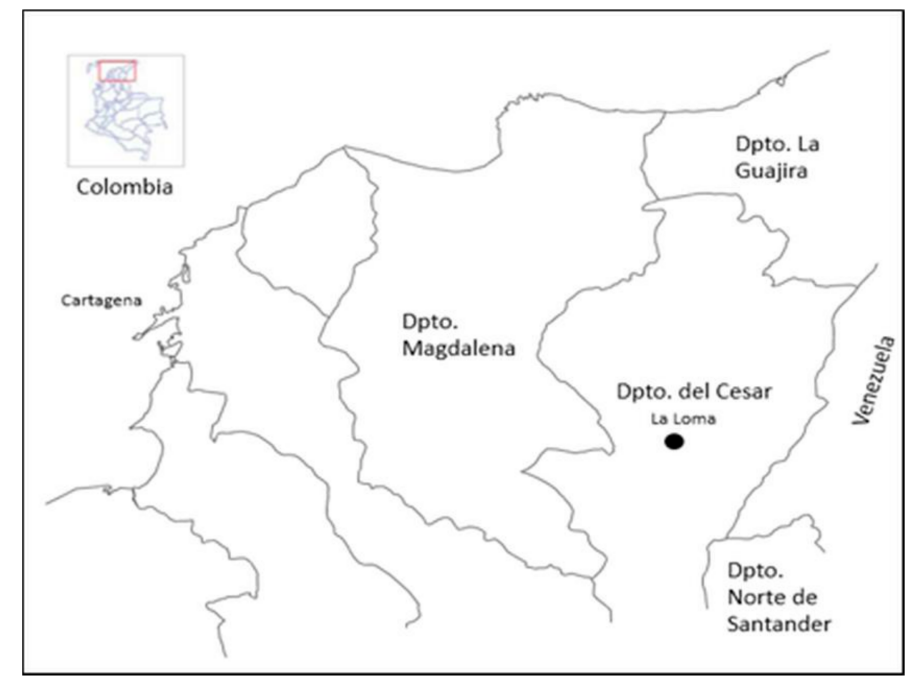

Figure 1. Location of the study area.

\subsection{Biochar Origin}

Biochar sample was provided by the Colombian Oil Palm Research Center (Centro de Investigación en Palma de Aceite, CENIPALMA). The analyzed sample corresponds to biocarbon obtained from stipe (trunk) of Oil Palm by carbonization in a TPI portable metal oven (designed by the Tropical Products Institute) reported by FAO. The sample comes from a low technology system where the pyrolysis time depends on the temperatures that the oven can reach with a maximum of 400 and minimum of $200{ }^{\circ} \mathrm{C}$ nonuniformly [36].

\subsection{Characterization of Efflorescent Salts and Biochar}

The coal mine waste samples were characterized using the Sobek method [37]. Color was measured by comparison with color chips based on the Munsell color system. Soil texture was analyzed utilizing a Bouyoucos hydrometer. The $\mathrm{pH}$ and $\mathrm{EC}$ were measured using a $\mathrm{pH} / \mathrm{EC}$ meter ( $\mathrm{pH}$-metro Orion Scientific Waltham). Efflorescent salt was measured in a soil/water ratio of 1:1 (w/v) suspension, while biochar samples were measured in water at a 1:5 $(v / v)$ ratio. $\mathrm{pH}$ and $\mathrm{EC}$ response as a function of biochar content $(0,5,10,15, \ldots$, and $50 \% v / v)$ were measured in saturated paste made by adding the required amount of biochar to $10 \mathrm{~mL}$ of the efflorescent salts [38]. Total nitrogen (TN) of the efflorescent salt was determined by the Kjeldahl method and soil organic carbon (SOC) by the Walkley-Black method, while extractable $\mathrm{P}$, and carbon $(\mathrm{C})$, hydrogen $(\mathrm{H})$, nitrogen $(\mathrm{N})$, and $\mathrm{S}$ content in the biochar were determined using an CHNS elemental analyzer (LECO model Truspec). The oxygen content was calculated by mass difference $(100 \%-\mathrm{C}, \mathrm{H}, \mathrm{N}, \mathrm{S}$, and ash \%). The water holding capacity (WHC) and cation exchange capacity (CEC) were measured according to the Colombian Technical Norm (NTC) 5167 [39]. The total concentrations of $\mathrm{Al}, \mathrm{Mn}, \mathrm{Zn}, \mathrm{Fe}$, and $\mathrm{Cu}$ were determined by atomic absorption spectrometry (AAS) after acid digestion using GBC 932 Plus equipment, according to method 3050b [40]. X-ray diffraction patterns were collected using a Rigaku MiniFlex X-ray diffractometer with a $\mathrm{Cu} \mathrm{K} \alpha$ source $(\lambda=1.5406 \AA)$ in Bragg-Brentano geometry. The data was collected in the range $20^{\circ}-80^{\circ}$ in $2 \theta$ with a scanning speed of $0.05^{\circ}$ per minute, and a probe size less than $0.044 \mathrm{~mm}$. The XRD pattern of the efflorescent salts was analyzed using the Xpowder 2004, 2010.01.10 software (Informer Technologies Inc., Los Angeles, CA, USA). The FTIR measurements were performed with a Nicolet 6700 FTIR spectrometer (Thermo Scientific) using a Thermo Scientific smart diffuse reflectance accessory [41]. Scanning electron microscopy (SEM) was carried out in JEOL JSM 6490. 


\subsection{Petri Dish Bioassays}

Germination percentage and root growth were established according to Solaiman et al. [25]. Fifty seeds of brachiaria (Brachiaria decumbens) were planted in Petri dishes $(8.5 \mathrm{~cm}$ in diameter) on a layer of filter paper moistened with deionized water. Then, $0,1.0,3$, and $5.0 \mathrm{~g}$ of efflorescent salts and 0 , $1,2.5$, and $5 \mathrm{~g}$ of biochar were mixed respectively. All Petri dishes were covered and incubated in the dark at $25{ }^{\circ} \mathrm{C}$ for 10 days. The root lengths of the seedlings in each Petri dish were measured with a ruler.

\subsection{Statistical Analysis}

Seed germination and root length data were statistically analyzed using ANOVA, and the significant mean values were identified by Duncan's multiple range test (DMRT). Each seed germination treatment bioassay was performed in triplicate.

\section{Results and Discussion}

The physical and chemical characteristics and elemental composition of the efflorescent salts and biochar are summarized in Table 1. The high EC in the efflorescent salts in comparison to the biochar is due to the higher content of charged species. As can be observed, these residues are rich in iron with high content of sulfates, calcium, and aluminum. Additionally, a significant presence of $\mathrm{Na}$, followed by minor amounts of $\mathrm{Mg}, \mathrm{K}, \mathrm{Cu}$, and $\mathrm{Mn}$, was detected. The $\mathrm{EC}$ of the efflorescent salts was higher than $8 \mathrm{dS} / \mathrm{m}$ but lower than $16 \mathrm{dS} / \mathrm{m}$, hence the material can be classified as highly saline sodic [42].

The waste heaps in the coal mines studied show features similar to those studied in North-Central Colorado, USA, which appear to be a potential source of trace elements and salinity [1,11].

Table 1. Summary of the physical-chemical properties of the efflorescent salt waste and biochar.

\begin{tabular}{|c|c|c|c|}
\hline References & Units & Salt Mine Spoil & Biochar \\
\hline $\mathrm{pH}$ & & 8.85 & 8.92 \\
\hline EC & $\mathrm{dS} / \mathrm{m}$ & 13.37 & 0.24 \\
\hline Sand & $\%$ & 53 & - \\
\hline Silt & $\%$ & 33.5 & - \\
\hline Clay & $\%$ & 13.5 & - \\
\hline WHC & $\%$ & - & 241.6 \\
\hline Soil texture & - & Sandy loam & - \\
\hline Munsell color (dry) & - & 10YR 9.5/1 & 2.5Gley $1 / \mathrm{N}$ \\
\hline SOC & $\%$ & 1.06 & 0.68 \\
\hline $\mathrm{P}$ & $\mathrm{mg} / \mathrm{kg}$ & 37.7 & - \\
\hline $\mathrm{N}$ Total & $\%$ & 0.13 & - \\
\hline CEC & $\left(\operatorname{cmol}(+) \mathrm{kg}^{-1}\right)$ & 36 & 42.80 \\
\hline $\mathrm{Ca}$ & $\mathrm{mg} / \mathrm{kg}$ & 9480.0 & 129.80 \\
\hline $\mathrm{Na}$ & $\mathrm{mg} / \mathrm{kg}$ & 3591.2 & 1620 \\
\hline $\mathrm{Mg}$ & $\mathrm{mg} / \mathrm{kg}$ & 302.6 & 34.70 \\
\hline K & $\mathrm{mg} / \mathrm{kg}$ & 288.5 & 109.76 \\
\hline Sulfates & $\mathrm{mg} / \mathrm{kg}$ & $11,814.62$ & - \\
\hline Total copper & $\mathrm{mg} / \mathrm{kg}$ & 37.88 & 3.20 \\
\hline Total zinc & $\mathrm{mg} / \mathrm{kg}$ & 314.46 & 35.13 \\
\hline Total iron & $\mathrm{mg} / \mathrm{kg}$ & $37,208.37$ & 211.36 \\
\hline Total aluminum & $\mathrm{mg} / \mathrm{kg}$ & 8702.29 & 284.82 \\
\hline Total manganese & $\mathrm{mg} / \mathrm{kg}$ & 490.43 & 47.44 \\
\hline $\mathrm{S}$ & $\%$ & 2.20 & 0.15 \\
\hline $\mathrm{C}$ & $\%$ & - & 70.10 \\
\hline $\mathrm{H}$ & $\%$ & - & 2.81 \\
\hline $\mathrm{N}$ & $\%$ & - & 0.86 \\
\hline $\mathrm{O}$ & $\%$ & - & 25.16 \\
\hline
\end{tabular}


The XRD pattern of the efflorescent salts is displayed in Figure 2. Quartz $=\mathrm{Q}\left(\mathrm{SiO}_{2}\right)$ and gypsum $=\mathrm{G}\left(\mathrm{CaSO}_{4} \cdot \mathrm{H}_{2} \mathrm{O}\right)$ are the major minerals although considerable amounts of alunite $=\mathrm{A}$ $\left(\mathrm{KAl}_{3}\left(\mathrm{SO}_{4}\right)_{2}(\mathrm{OH})_{6}\right)$ and natrojarosite $=\mathrm{N}\left(\mathrm{NaFe}_{3}\left(\mathrm{SO}_{4}\right)_{2}(\mathrm{OH})_{6}\right)$ and minor amounts of calcite $=\mathrm{C}$ $\left(\mathrm{CaCO}_{3}\right)$ and halite $=\mathrm{H}(\mathrm{NaCl})$ were also observed. The diffraction pattern of the salts' residues confirms the diversity of crystalline solids waste in the sample. Although pyrite and schwertmannite have often been reported in drainage acids of coal mines [43], it was not possible to identify these phases in the XRD analysis. Although elemental analysis in efflorescent salts showed the presence of sulfur, it may be that pyrite cannot be observed in the XRD pattern due to the insensitivity of the technique.

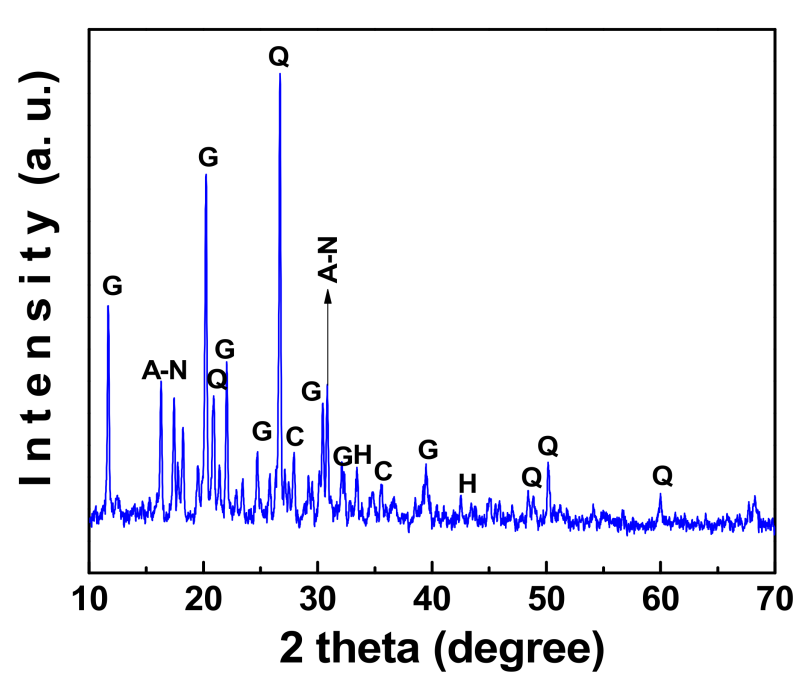

Figure 2. XRD pattern of the efflorescent salts. $Q=$ quartz, $G=$ gypsum, $A=$ alunite, $N=$ natrojarosite, $\mathrm{C}=$ calcite, and $\mathrm{H}=$ halite $(\mathrm{NaCl})$.

The XRD pattern of biochar is presented in Figure 3. Two broad bands centered at $2 \theta=22.5^{\circ}$ and $2 \theta=43^{\circ}$ indicate the presence of graphene in this sample. The formation of graphene sheets could occur during the pyrolysis process of waste materials derived from oil palm cultivation. Similar diffraction patterns were obtained by Zhang et al. [32] and Saikia et al. [44] in studies of biochar and bituminous coal graphenes, respectively.

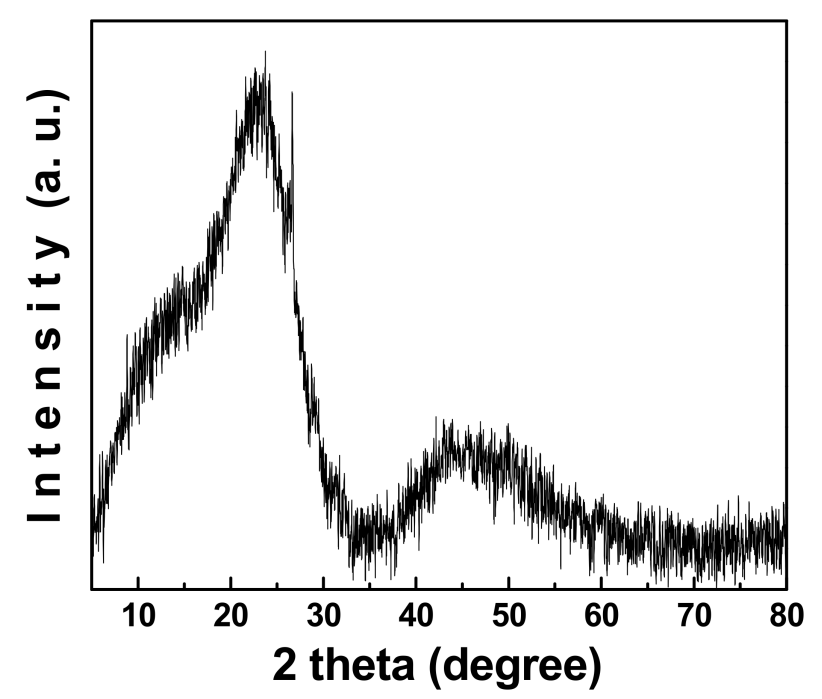

Figure 3. XRD pattern of biochar derived from the waste materials of oil palm cultivation. 
Figure 4 shows SEM images of efflorescent salts (top panel) and biochar (bottom panel) at different magnifications. In the efflorescent salts, the presence of irregular particles with a wide range of sizes is observed, along with a great and well-defined regular structure, with either a hexagonal and/or monoclinic habit, possibly related to the presence of gypsum and/or alunite-natrojarosite. On the other hand, according to the bottom panel, the biochar seems to have developed high irregular longitudinal porosity, keeping the structural components of the biomass, indicating that thermal degradation had not been completed.
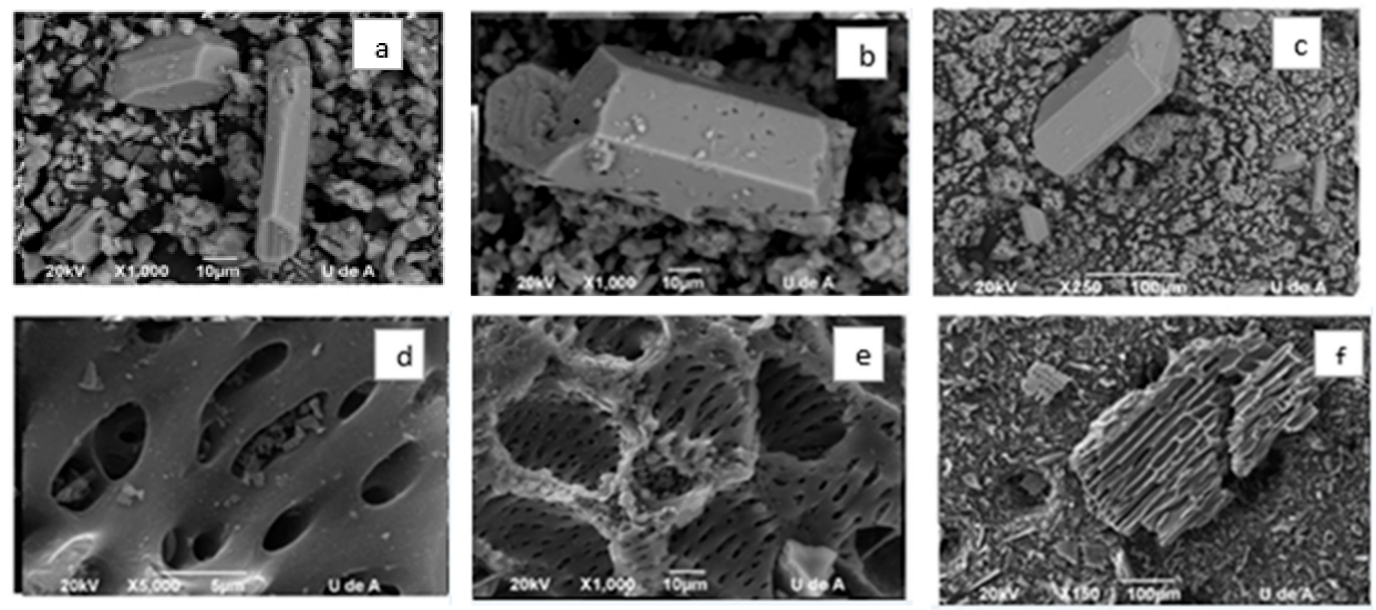

Figure 4. SEM micrographs of $(\mathbf{a}-\mathbf{c})$ efflorescent salts and $(\mathbf{d}-\mathbf{f})$ biochar.

Figure 5 shows the FTIR spectrum in the wavenumber range of $800-4000 \mathrm{~cm}^{-1}$ for the biochar sample. The broad band centered at around $3422 \mathrm{~cm}^{-1}$ is assigned to the stretching vibrational modes of hydroxyl groups. The spectrum exhibits two very weak peaks located at $\sim 2850$ and $2925 \mathrm{~cm}^{-1}$ due respectively to $\mathrm{C}-\mathrm{H}$ bond bending and stretching from aliphatic groups. The absorptions at $1560 \mathrm{~cm}^{-1}$ and $1380 \mathrm{~cm}^{-1}$ can be attributed to the antisymmetric and symmetric $\mathrm{C}=\mathrm{O}$ stretching modes, commonly associated with the carboxylate functional group. Finally, the bands between $1050 \mathrm{~cm}^{-1}$ and $1300 \mathrm{~cm}^{-1}$ may be assigned to $\mathrm{C}-\mathrm{O}$ bonds. The functional groups identified in this spectrum are similar to these found by Cantrell et al. [45] in biochar poultry litter studies. The waste heaps in the coal mines studied show features similar to those studied in North-Central Colorado, USA, which appear as a potential source of trace elements and salinity $[1,11]$.

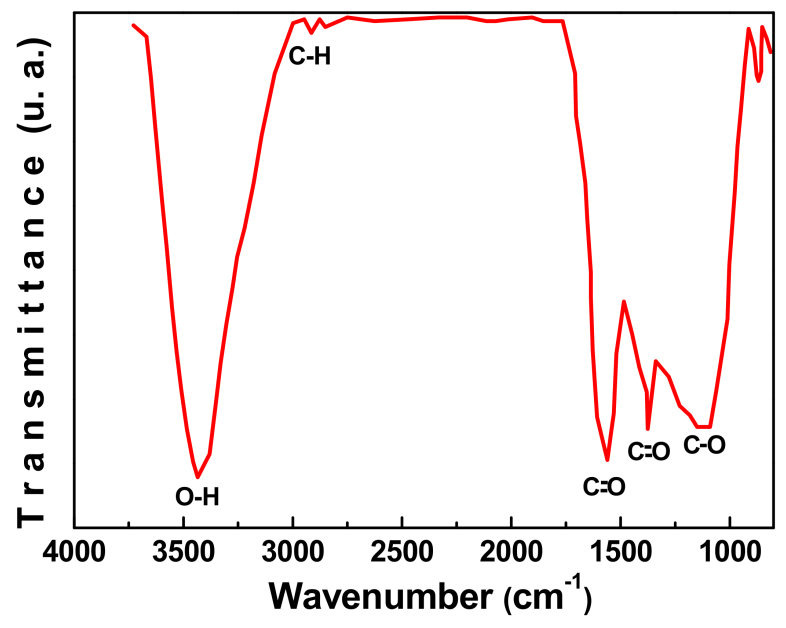

Figure 5. FTIR spectrum of the biochar. 
As shown in Figure 6a, a significant increase in EC was observed following the increase from $5 \%$ to $10 \%$ biochar. Similar behavior was reported by Abdel-Fattah [46], in which the salts can be readily leached during the first leaching period. Figure $6 \mathrm{~b}$ shows the $\mathrm{pH}$ variation as a function of the biochar content. It can be seen that the biochar addition increased the $\mathrm{pH}$ of the saline substratum. Additionally, when the efflorescent salt was mixed with 5\% biochar, the $\mathrm{pH}$ changed from 8.32 to 8.38 , which is equivalent to $31.58 \%$ of the total variation achieved. Many amendments and soil improvement products require long periods of time to adjust and balance the $\mathrm{pH}$ and EC.
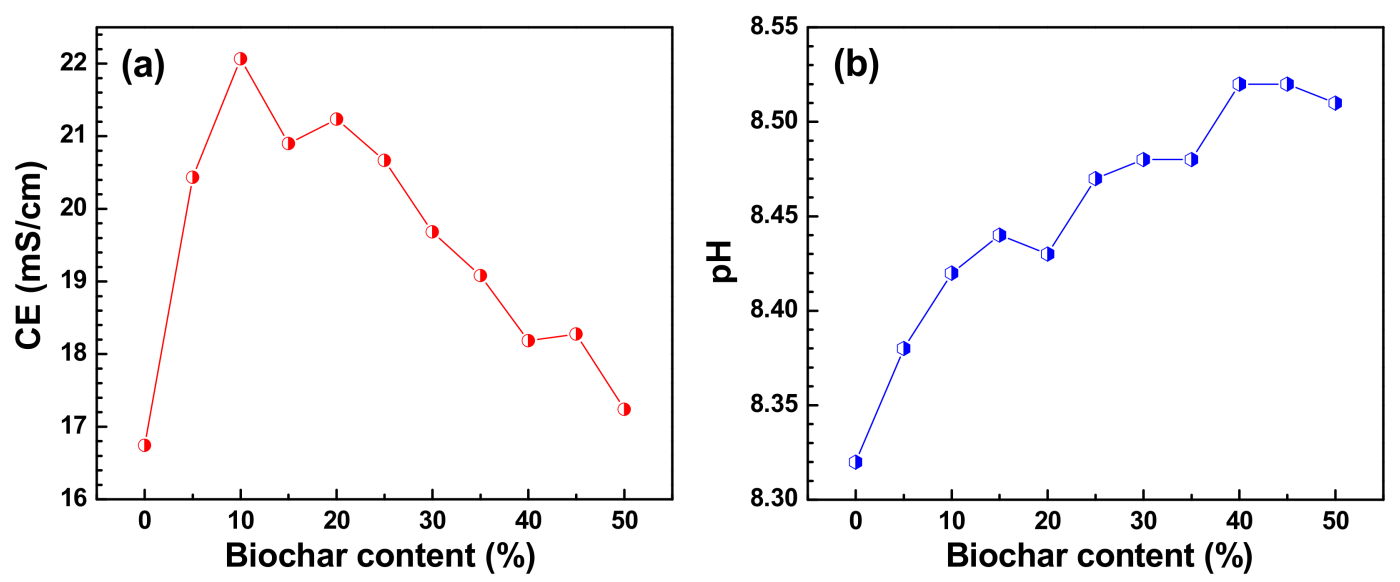

Figure 6. (a) EC and (b) pH curves of the mixture of biochar and efflorescent salt.

The germination percentage and root length of brachiaria grass in the presence of efflorescent salts and biochar are shown in Figure $7 \mathrm{a}, \mathrm{b}$. The inhibition of germination and root elongation compared with that of the control depended on the salt content. In general, the percentage of seed germination and root length increased with the addition of biochar. Because of the results obtained, Petri dish bioassays are considered a valid method for assessing toxicity problems associated with various materials, including mining waste and biosolids [25,47].
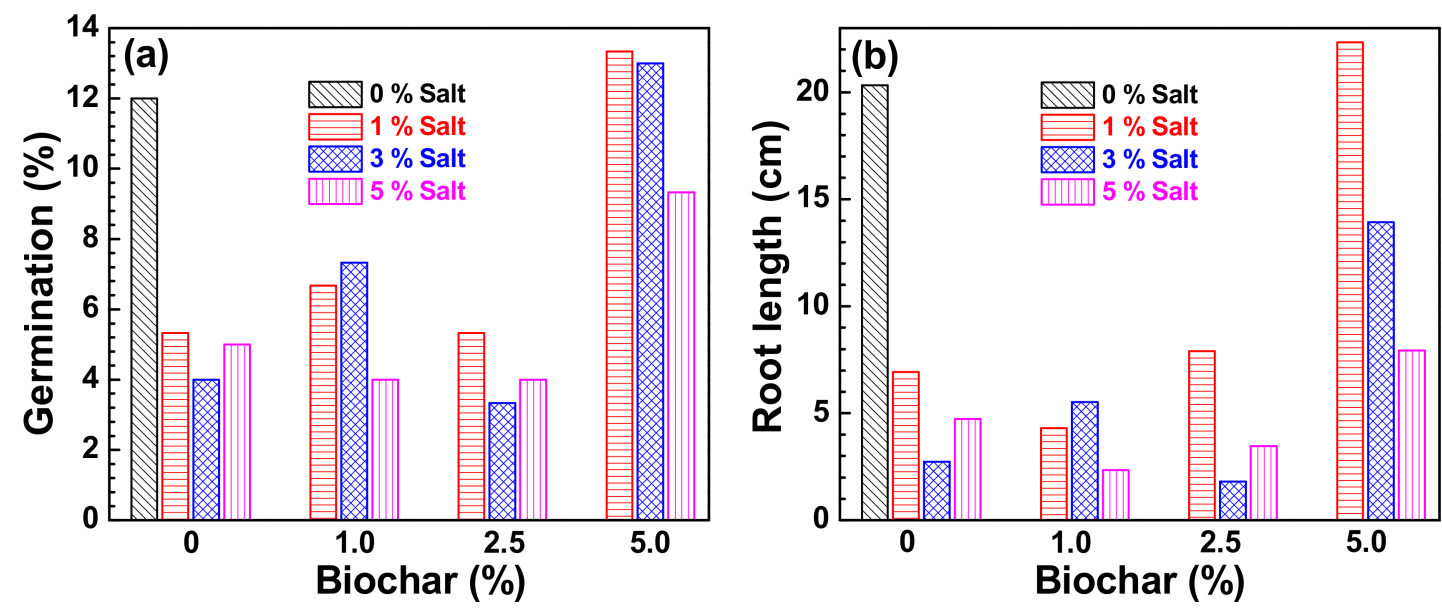

Figure 7. The effect of biochar on the (a) germination percentage and (b) the root length of seeds in Petri dish bioassays using efflorescent salts.

The ANOVA results showed that the germination percentage and root lengths of the brachiaria grass were significantly affected by the concentration of the salts $(p<0.05)$ (Table 2$)$, and that biochar positively improved these properties. The germination percentage was higher for treatments with the highest percentage of biochar (13.33\%) and for the control, which lacked both salt and biochar (12\%). 
The root lengths were also recorded for the highest dose of biochar $(22.37 \mathrm{~cm})$ and targets $(20.03 \mathrm{~cm})$. The germination percentage of brachiaria significantly $(p<0.05)$ decreased with increasing salt content; high concentrations of soluble salts were also detrimental to the growth of this plant.

Table 2. Effect of biochar on seed germination and root length in a Petri dish bioassay with secondary salt on mine waste. ANOVA results with factorial analysis for the samples in Petri dishes, according to germination and root length.

\begin{tabular}{cccc}
\hline Factor & df & $\begin{array}{c}\text { Brachiaria } \\
\text { Germination }\end{array}$ & $\begin{array}{c}\text { Brachiaria } \\
\text { Root Length }\end{array}$ \\
\hline Mine waste with salt dose & 2 & 0.4527 & $0.0066^{*}$ \\
Biochar dose & 3 & $0.0001^{*}$ & $0.0000^{*}$ \\
Biochar dose $\times$ soil type & 6 & 0.7068 & 0.1172 \\
\hline
\end{tabular}

A linear correlation was noted between soil characteristics, seed germination, root and shoot growth $(* p<0.05)$.

According to the multiple percentage test (Table 3), the germination and root length of the control target showed significant differences for the groups treated with efflorescent salt and biochar. The presence of efflorescent salt negatively affected the elongation of the brachiaria grass roots $(p<0.05)$; for the treatments carried out with the presence of salt. Differences were only observed between the groups with the highest and lowest salt concentrations. The effect of the addition of biochar on germination and root growth in the presence of salt showed that the group treated with the highest dose of biochar was significantly different from the others. The results are conclusive: the biochar enhanced the germination and root length properties. Similar findings have been reported with other tested precursors of biochar $[35,48]$. The reduction in phytotoxicity after the application of biochar can probably be explained by the decrease in metals and osmotic toxicity, as identified by Abari et al. [49]. According to Wang et al. [50], the results obtained from the efflorescent salt waste and basic information on the phytotoxicity of such waste with respect to germination and root elongation is required for the evaluation of ecological risk type. As a rapid phytotoxicity test method, the approach used here presents advantages such as sensitivity, simplicity, low cost, and convenience with respect to the use of unstable chemicals or samples.

Table 3. The mean values of biochar effect on seed germination and root length.

\begin{tabular}{ccc}
\hline \multicolumn{3}{c}{ Brachiaria Root Length $\mathbf{( c m )}$} \\
\hline Biochar percent & Mean & Homogeneous groups \\
\hline 0 & 4.8 & $\mathrm{a}$ \\
1 & 4.07 & $\mathrm{a}$ \\
2.5 & 4.39 & $\mathrm{a}$ \\
5 & 14,7 & $\mathrm{~b}$ \\
\hline \multicolumn{4}{c}{ Brachiaria Germination $\mathbf{( \% )}$} \\
\hline Biochar percent & Mean & Homogeneous groups \\
\hline 0 & 4.78 & $\mathrm{a}$ \\
2.5 & 5.33 & $\mathrm{a}$ \\
5 & 4.22 & $\mathrm{a}$ \\
\hline
\end{tabular}

In the near future, more tests will be required to reduce any errors arising from the experiments. Another constraint is the scaling of biochar remediation from Petri dishes to pots and experimental plots. 


\section{Conclusions}

We characterized efflorescent salts and biochar used as an amendment for the remediation of soils in a coal mining area in the north of Colombia. Efflorescent salt is dominated mainly by quartz and gypsum with appreciable amounts of alunite and natrojarosite and minor amounts of calcite and halite, with high concentrations of sulfates, $\mathrm{Fe}$, and $\mathrm{Al}$, as well as minor amounts of $\mathrm{Ca}, \mathrm{Na}, \mathrm{Mg}$, and $\mathrm{K}$. It has electrical conductivity. The soil $\mathrm{pH}$ increased due to the addition of biochar developed from crop residues of palm oil. The present study demonstrated that efflorescent saline stress from coal mining affects the germination and growth of brachiaria grass. The results of this study also suggest that biochar can improve germination properties in mine soil containing efflorescent salts as a result of coal mining, and showed biochar to be effective in the restoration of soil. These results are very important for designing repair strategies for soils in coal mining areas in the north of Colombia.

Acknowledgments: The authors are grateful for the financial support from COLCIENCIAS (Departamento Administrativo de Ciencia, Tecnología e Innovación) program 1115-576-35893, GDCON Research Group of UdeA (Universidad de Antioquia), Jesus García Processing program coordinator (CENIPALMA).

Author Contributions: Luis Diaz performed the physicochemical analysis laboratoy of salt residues, characterization of biochar, phytotoxicity tests and wrote the manuscript; Julio Arranz, performed the mineralogical characterization of salt residues and analysis of results; Gustavo Peñuela performed the field sampling, supervised the experiments and revised the manuscript.

Conflicts of Interest: The authors declare no conflict of interest.

\section{References}

1. Zielinski, R.A.; Otton, J.K.; Johnson, C.A. Source of salinity near a coal mine spoil mine pile, North-Central Colorado. J. Environ. Qual. 2001, 30, 1237-1248. [CrossRef] [PubMed]

2. Ghose, M.; Kundu, N.K. Deterioration of soil quality due to stockpiling in coal mining areas. Int. J. Environ. Stud. 2003, 61, 327-335. [CrossRef]

3. Arranz-González, J.C. Caracterización geoambiental de lugares alterados por minería de carbón en la provincia de León (España). Bull. Geol. Min. 2006, 117, 171-186.

4. Arranz-González, J.C. Mine soils associated with open-cast coal mining in Spain: A review. Nezwslett. Geol. Min. 2011, 122, 171-186.

5. Park, J.H.; Li, X.; Edraki, M.; Baumgartl, K.B. Geochemical assessments and classification of coal mine spoils for better understanding of potential salinity issues at closure. Environ. Sci. Process. Impacts 2013, 15, 1235-1244. [CrossRef] [PubMed]

6. Schaaf, W.; Huttl, R. Direct and indirect effects of soil pollution by lignite mining. Water Air Soil Pollut. 2006, 6, 353-364. [CrossRef]

7. Daniels, W.; Zipper, C. Creation and Management of Productive Mine Soils; Reclamation Guidelines; Publication No. 460-121; Virginia Cooperative Extension Publication: Blacksburg, VA, USA, 1997; pp. 1-13.

8. Almansouri, M.; Kinet, J.; Lutts, S. Effect of salt and osmotic stresses on germination in durum wheat (Triticum durum). Plant Soil 2001, 231, 243-254. [CrossRef]

9. Khajeh-Hosseini, M.; Powell, A.; Bimgham, I. The interaction between salinity stress and force during seed germination of soybean seeds. Seed Sci. Technol. 2003, 31, 715-725. [CrossRef]

10. Cook, S.; Shu, A.; Goodman, S. Leachability and toxicity of hydrocarbons, metals and salt contamination from flare pit soil. Water Air Soil Pollut. 2002, 133, 297-314. [CrossRef]

11. Hammarstrom, J.; Seal, R.; Meier, A.; Kornfeld, J. Secondary sulfate minerals associated with acid drainage in the eastern US: Recycling of metals and acidity in surficial environments. Chem. Geol. 2005, 215, 407-431. [CrossRef]

12. O'Day, A.; Vlassopoulos, D. Mineral-Based amendments for remediation. Elements 2010, 6, 375-381. [CrossRef] [PubMed]

13. Hudson, B.E. Soil organic matter and available water capacity. J. Soil Water Conserv. 1994, 49, $189-194$.

14. Tryon, E.H. Effect of charcoal on certain physical, chemical, and biological properties of forest soils. Ecol. Monogr. 1948, 18, 81-115. [CrossRef] 
15. Briggs, C.M.; Breiner, J.; Graham, R.C. Contributions of Pinus Ponderosa charcoal to soil chemical and physical properties. In Proceedings of the ASA-CSSA-SSSA International Annual Meetings, Salt Lake City, UT, USA, 6-10 November 2005.

16. Gundale, M.J.; Deluca, T.H. Temperature and source material influence ecological attributes of Ponderosa pine and Douglas-fir charcoal. For. Ecol. Manag. 2006, 231, 86-93. [CrossRef]

17. Liang, B.; Lehmann, J.; Solomon, D.; Kinyangi, J.; Grossman, J.; O’Neill, B.; Skjemstad, J.O.; Thies, J.; Luizao, F.J.; Petersen, J.; et al. Black coal increases cation exchange capacity in soils. Soil Sci. Soc. Am. J. 2006, 70, 1719-1730. [CrossRef]

18. Glaser, B.; Lehmann, J.; Zech, W. Ameliorating physical and chemical properties of highly libre soils in the tropics with charcoal-A review. Biol. Fertil. Soils 2002, 35, 219-230. [CrossRef]

19. Diaz-Muegue, L.; Pinto, N.; Peñuela, G. Characterization of biochar from palm oil waste and remediation of mine waste and land affected by opencast coal mining. In Proceedings of the Annual World Conference on Carbon, Rio de Janeiro, Brazil, 14-19 July 2013.

20. Diaz-Muegue, L.; Pinto, N.; Peñuela, G. Biochar from oil plan waste as an amendment for the remetiation of soil disturbed by open-cast coal mining. Glob. Adv. Res. J. Eng. 2016, 5, 17-22.

21. Lehmann, J.; Joseph, S. Biochar for Environmental Management: Science and Technology; Earthscan: Sterling, VA, USA, 2009; ISBN 978-1-84407-65-1.

22. Masulili, A.; Utomo, W.H.; MS, S. Rice Husk Biochar for Rice Based Cropping System in Acid Soil 1. The Characteristics of Rice Husk Biochar and Its Influence on the Properties of Acid Sulfate Soils and Rice Growth in West Kalimantan, Indonesia. J. Agric. Sci. 2010, 2, 39-47. [CrossRef]

23. Chan, K.Y.; Van Zwieten, L.; Meszaros, I.; Downie, A.; Joseph, S. Agronomic values of greenwaste biochar as a soil amendment. J. Soil Res. 2007, 45, 629-634. [CrossRef]

24. Atkinson, C.J.; Fitzgerald, J.D.; Hipps, N.A. Potential mechanisms for achieving agricultural benefits from biochar application to temperate soils: A review. Plant Soil 2010, 337, 1-18. [CrossRef]

25. Solaiman, Z.; Murphy, D.; Abbott, L.K. Biochars influence seed germination and early growth of seedlings. Plant Soil 2010, 353, 273-287. [CrossRef]

26. Free, H.F.; McGill, C.R.; Rowarth, J.S.; Hedley, M.J. The effect of biochars on maize (Zea mays) germination. N. Z. J. Agric. Res. 2010, 53, 1-4. [CrossRef]

27. Uchimiya, M.; Klasson, K.T.; Wartelle, L.H.; Lima, I.M. Influence of soil properties on heavy metal sequestration by biochar amendment: 1 . Copper sorption isotherms and the release of cations. Chemosphere 2011, 82, 1431-1437. [CrossRef] [PubMed]

28. Bartell, F.E.; Miller, E.J. Adsorption by activated sugar charcoal. II. J. Am. Chem. Soc. 1923, 45, 1106-1115. [CrossRef]

29. Zou, L.; Morris, G.; Qi, D. Using activated carbon electrode in electrosorptive deionization of brackish water. Desalination 2008, 225, 329-340. [CrossRef]

30. Thomas, S.; Frye, S.; Gale, N.; Garmon, M.; Launchbury, R.; Machado, N.; Melamed, S.; Murray, J.; Petroff, A.; Winsborough, C. Biochar mitigates negative effects of salt additions on two herbaceous plant species. J. Environ. Manag. 2013, 129, 62-68. [CrossRef] [PubMed]

31. Yang, Y.; Ma, S.; Zhao, Y.; Jing, M.; Xu, Y.; Chen, J. Field Experiment on Enhancement of Crop Yield by Rice Straw and Corn Stalk-Derived Biochar in Northern China. Sustainability 2015, 7, 13713-13725. [CrossRef]

32. Zhang, M.; Gao, B.; Yao, Y.; Xue, Y.; Mandu, I. Synthesis, characterization, and environmental implications of graphene-coated biochar. Sci. Total Environ. 2012, 435, 567-572. [CrossRef] [PubMed]

33. Sheoran, V.; Sheoran, A.; Poonia, P. Soil reclamation of abandoned mine land by revegetation: A Review. Int. J. Soil Sediment Water 2010, 3, 1-20.

34. Deenik, J.; Cooney, M. The Potential Benefits and Limitations of Corn Coband Sewage Sludge Biochars in an Infertile Oxisol. Sustainability 2016, 8, 131. [CrossRef]

35. Beesley, L.; Moreno-Jiménez, E.; Gomez-Eyles, J.; Harris, E.; Robinson, B.; Sizmur, T. A review of biochars' potential role in the remediation, revegetation and restoration of contaminated soils. Environ. Pollut. 2011, 159, 3269-3282. [CrossRef] [PubMed] 
36. Garcia-Perez, M.; Kruger, C.; Fuchs, M.; Sokhansanj, S.; Badger, P.; Garcia-Nunez, J.; Lewis, T.; Kantor, S. Methods for Producing Biochar and Advanced Biofuels in Washington State Part 2: Literature Review of the Biomass Supply Chain and Preprocessing Technologies from Field to Pyrolysis Reactor; Publication No. 12-07-033; Department of Biological Systems Engineering, Center for Sustaining Agriculture Natural Resources: Pullman, WA, USA, 2012.

37. Sobek, A.A.; Schuller, W.A.; Freeman, J.R.; Smith, R.M. Field and Laboratory Methods Applicable to Overburdens and Minesoils; EPA-600r2-78-054; United States Environmental Protection Agency (U.S. EPA): Cincinnati, OH, USA, 1978.

38. Warncke, D.D. Analyzing greenhouse growth media by the saturation extraction method. Hortic. Sci. 1986, 21, 223-225.

39. Instituto Colombiano de Normas Técnicas y Certificación (ICONTEC). Standard for Agricultural Industry Products, Organics Products Used as Fertilizers and Soil Amendments NTC 5167; Instituto Colombiano de Normas Técnicas y Certificación: Bogotá, Colombia, 2004; pp. 1-32.

40. United States Environmental Protection Agency (US EPA). SW-846 Reference Methodology: Method 3050B. Standard Operating Procedure for the Digestion of Soil/Sediment Samples Using a Hotplate/Beaker Digestion Technique; U.S. Environmental Protection Agency: Chicago, IL, USA, 1999; pp. 1-12.

41. Singh, B.; Fang, Y.; Johnston, C.T. A Fourier-Transform Infrared Study of Biochar Aging in Soils. Soil Sci. Soc. Am. J. 2016, 80, 613-622. [CrossRef]

42. Office of Surface Mining Reclamation and Enforcement (OSMRE). Overburden Sampling and Analytical Quality Assurance and Quality Control (QA/QC) Requirements for Soils, Overburden, and Regraded Spoil Characterization and Monitoring Programs for Federal Lands in the Southwestern United States; Office of Surface Mining Reclamation and Enforcement, U.S. Department of the Interior, Western Regional Coordinating Center: Denver, CO, USA, 1998.

43. Murad, E.; Rojik, P. Iron-rich precipitates in a mine drainage environment: Influence of $\mathrm{pH}$ on mineralogy mapper. Am. Mineral. 2003, 88, 1915-1918. [CrossRef]

44. Saikia, B.; Boruah, R.; Gogoi, P. A X-ray diffraction analysis on graphene layers of Assam coal. J. Chem. Sci. 2009, 121, 103-106. [CrossRef]

45. Cantrell, K.; Hunt, P.; Uchimiya, M.; Novak, J. Impact of pyrolysis temperature and manure source on physicochemical characteristics of biochar. Bioresour. Technol. 2012, 107, 419-428. [CrossRef] [PubMed]

46. Abdel-Fattah, M. Role of gypsum and compost in reclaiming saline-sodic soils. J. Agric. Vet. Sci 2012, 30-38. [CrossRef]

47. Organization for Economic Co-operation and Development (OECD). Terrestrial Plant Test: Seedling Emergence and Seedling Growth Test; OECD Guidelines for Testing of Chemicals 208; Organization for Economic Co-operation and Development: Paris, France, 1984; pp. 1-6.

48. Oleszczuk, P.; Malara, A.; Jośko, I.; Lesiuk, A. The Phytotoxicity changes of sewage sludge-amended soils. Water Air Soil Pollut. 2012, 223, 4937-4948. [CrossRef] [PubMed]

49. Abari, A.; Nasr, M.H.; Hojjati, M.; Bayat, D. Salt effects on seed germination and seedling emergence of two Acacia species. Afr. J. Plant Sci. 2011, 5, 52-56.

50. Wang, X.; Sung, C.; Gao, S.; Wang, L. Variation of germination rate and root elongation as indicator to assess phytotoxicity with Cucumis sativus. Chemosphere 2001, 44, 1711-1721. [CrossRef] 